Cuatreros de la memoria

Lía Gómez

Tram[p]as de la comunicación y la cultura (N. ${ }^{\circ}$ 81), e015, abril-septiembre 2017

ISSN 2314-274X | https://doi.org/10.24215/2314xe015

http://perio.unlp.edu.ar/ojs/index.php/trampas/index

FPyCS | Universidad Nacional de La Plata

La Plata | Buenos Aires | Argentina

Lía Gómez lialaig@gmail.com

http://orcid.org/0000-0002-1377-8167

Instituto de Estudios Comunicacionales en Medios, Cultura y Poder

«Aníbal Ford» (INESCO) Facultad de Periodismo y Comunicación Social

Universidad Nacional de La Plata

Argentina

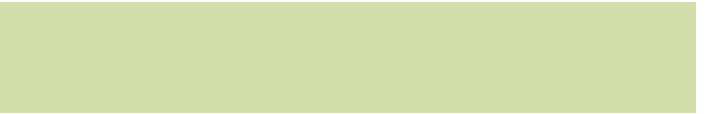

Resumen

El escrito aborda el último filme de la cineasta argentina Albertina Carri, Cuatreros (2016), a partir de la relectura del texto Isidro Velázquez. Formas pre revolucionarias de la violencia (1968), del sociólogo, y padre de Albertina, Roberto Carri, detenido desaparecido por la última Dictadura cívico militar argentina. Este libro, reeditado en 2015 por la Biblioteca Nacional, recorre toda la obra del escritor, cuyo problema central lo constituye la construcción de las formas de la memoria.

\section{Palabras clave}

cine, memoria, Albertina Carri

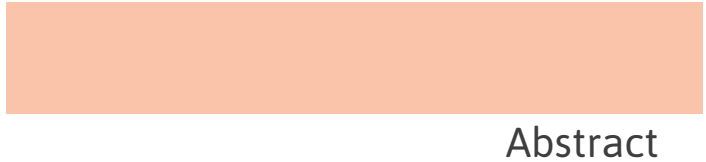

The article proposes considering the last film of Argentine filmmaker Albertina Carri, Cuatreros (2016), from the re reading of the text Isidro Velazquez. Formas pre revolucionarias de la violencia (1968), by the sociologist, and Albertina`s father, Roberto Carri, disappeared by the last Argentine civilmilitary dictatorship. This book, reedited in 2015 by the National Public Library, goes over the filmmaker's work, in which the construction of memory and its mechanisms is the main subject.

\section{Keywords}

cinema, memory, Albertina Carri 


\title{
Cuatreros de la memoria
}

\author{
Memory Rustlers
}

En 2017 se cumplen 100 años del nacimiento del escritor Augusto Roa Bastos. Paraguayo de nacimiento, Roa Bastos llegó a la Argentina a fines de los años cuarenta, expulsado de su país por la dictadura, y nuevamente debió exiliarse luego del Golpe de Estado de 1976. En uno de sus cuentos más emblemáticos, «Encuentro con el Traidor», podemos leer:

Me viene siguiendo -dijo el hombre alto y canoso-. No puedo darme vuelta a esperarlo. ¿Qué le diría? ¿Puedo acaso ahora decirle la verdad, después de tantos años? Tampoco lo creería. La verdad también envejece, a veces más rápido que los hombres. Además, la verdad no es para los débiles... (Roa Bastos, 2017, p. 34). 


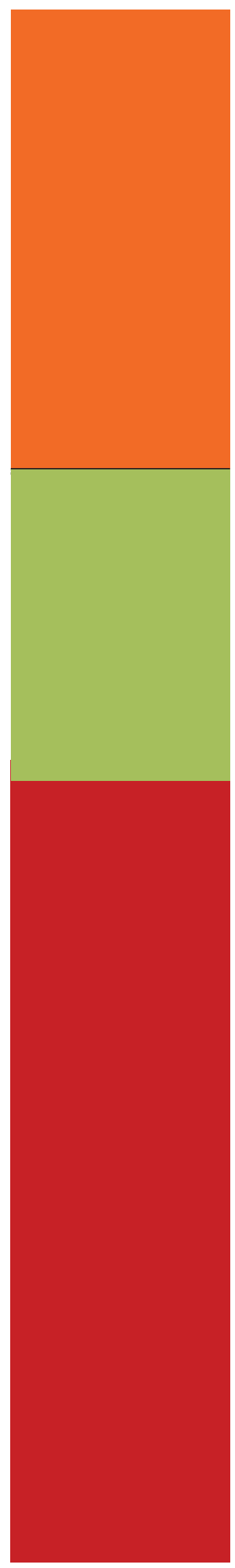

Época, además, de grandes temblores en el mundo social, cultural y político, e incluso en la universidad, que durante la dictadura de Juan Carlos Onganía viviría, en 1966, la «Noche de los bastones largos» y, en 1969, el "Cordobazo». Por esos años, Roa Bastos se preguntaba por el compromiso de asumir el riesgo de enfrentarse a una verdad, de ser parte de ella, de construirla con el peso incluso de la historia que la habita.

La verdad y la memoria son dos de los ejes centrales del cine de Albertina Carri. En Los Rubios (2003), su primer filme estrenado comercialmente, Albertina pareciera no poder darse vuelta a enfrentar la verdad de la memoria que se le acerca. En Cuatreros (2016), en cambio, la afronta y la enaltece con la valentía de descubrir las imágenes de un tiempo que transforman su vida y la de toda una generación.

Roa Bastos también fue guionista, como el padre de Albertina, Roberto Carri, quien participó de la adaptación de su libro Isidro Velázquez. Formas pre revolucionarias de la violencia (1968), filme que fue llevado al cine por Pablo Szir, cineasta y cinta ambos desaparecidos.

La desaparición forzada de personas, de objetos culturales, de historias y de identidades ha atravesado la escena audiovisual de múltiples formas, pero, sin duda, es en Cuatreros que se hace visible la complejidad de un mundo que es habitado por el horror de una época que aparece en las múltiples formas de la imagen. Desde fragmentos de noticieros diarios, con entrevistas en las que Lepoldo F. Galtieri habla sobre la paz en la Argentina en plena guerra de Malvinas, pasando por filmes coreanos escondidos en la cinemateca cubana, por imágenes de jóvenes que toman el colegio Carlos Bergara en Buenos Aires, por publicidades de época con cuerpos «subversivos», hasta una película española con una princesa negra. Pareciera ser que estos fragmentos de mundo, guardados en latas de fílmico por años, vuelven a la luz en un trabajo de montaje que enuncia lo ridículas que pueden tornarse las representaciones masivas en un mundo atormentado.

Albertina narra esta complejidad con una pantalla dividida que fracciona aún más la visión de la época, con un cruce inimaginable que pareciera querer describir la cotidianeidad en la que la niña Carri pasaba sus días, entre el andar a caballo en el monte y el recordar las últimas cartas que le habían enviado sus padres desde el Sheraton (centro clandestino de detención). 
¿Se puede vivir con la ausencia, incluso, de la muerte? ¿Es posible darse vuelta para enfrentar a los perpetradores? ¿Qué hacer con tantos muertos encima? Carri recorre su propia vida junto con la historia argentina y los indicios de las imágenes configuran una condición de real en la complejidad de la edificación de sus propios recuerdos. Enuncia y renuncia a comprenderlo todo para entender que conocer la verdad es parte de su viaje continuo en esta vida.

En Cuatreros, política, cine y memoria se yuxtaponen todo el tiempo. La misma Albertina, quien desde el offes protagonista de la película en todo momento, rememora su viaje a Chaco, su búsqueda intensa de la película de su padre; su encuentro con una tía que dice tener un hijo muerto nacido cien años antes, la presentación de Los Rubios (2003) en un cine escondido de la ciudad de Resistencia, donde encuentra a un joven que le habla de sus días en el monte con el libro de su padre.

Las contradicciones con la lucha de sus progenitores, con la condición casi fascista del capital, con la rabia de no haber llegado aún a juicio en la causa del Sheraton (donde estuvieron secuestrados desaparecidos sus padres) en los juicios de lesa humanidad, con tener en mano parte del guion de Los Velázquez (Szir \& Stantic, 1971-1972) con transcripciones de Vicky Walsh, muerta en combate en una emboscada militar.

Solo como aproximación al film, podríamos destacar tres puntos centrales de la narrativa: el primero es el de la propia Albertina, su vinculación con los Velázquez, con su padre, con su hijo Furio, con su cuerpo, con su condición de mujer, madre, lesbiana, militante, hija de desaparecidos, cineasta; el segundo, la historia de los sentidos que configuran las imágenes, el cine, la televisión, la prensa, las enunciaciones cotidianas que narran cada época con un absurdo tan obsceno que a veces solo el cine de ficción puede contrarrestar; el tercero, la pregunta por la nación argentina, por el pueblo, por su lucha, por la repetición, por el Estado, por los cruces que nos configuran en la actualidad, por la responsabilidad de cada generación.

Pareciera ser que los muros de silencio de la infancia de Carri se van desmoronando en la opción de narrar su propia vida ligada a la historia que la contiene. Ella asume eso en cada escena construida.

Voy tras los pasos de Isidro Velázquez, el último gauchillo alzado de la Argentina, y como la búsqueda del tiempo perdido siempre es errática, ¿voy detrás de los pasos de ese fugitivo de la justicia burguesa, o es que voy tras mis pasos, tras mi herencia? Viajo a Chaco, a Cuba, busco en archivos fílmicos cuerpos en movimiento de algo que se fue muy temprano... (Carri, 2016). 
Cuatreros (2016) se configura como un ensayo fílmico, como una escritura audiovisual, que, del mismo modo que el libro de Carri padre, invita a pensar la sociedad en su conjunto y a comprender que la política también es parte de la semántica del lenguaje.

La muerte de ambos [Isidro Velázquez y Vicente Gauna], el 1ero de diciembre de 1967, es el cierre aparente de un proceso, pero su leyenda sigue extendiéndose en la región y están a punto de convertirse en símbolo de la rebeldía y del descontento popular. [...] Al considerar a la cultura popular como la matriz de la que surge una política nacionalista y revolucionaria, en ella y solo en ella se encuentran las enseñanzas que guiarán la acción. Y Velázquez hoy ya es parte de la cultura de nuestro pueblo. El sentimiento que despertó su acción, su práctica concreta, son patrimonio de los oprimidos de las áreas rurales de Chaco (Carri, [1969] 2015, p. 283).

Roberto Carri encuentra en el caso de los bandoleros chaqueños la lucha popular por la liberación de la opresión, de las desigualdades. Desde el prólogo, enuncia cómo la oligarquía captura, incluso, la fecha de estos asesinatos como día de la policía de Chaco, cómo se apropia de la muerte y de la vida, y las resignifica para perpetrar en las narrativas la opresión. Los Velázquez, sin embargo, permanecen en las leyendas de la provincia, se recuperan en la película de Albertina y se reeditan en las múltiples ediciones del libro de su padre, que más allá de la historia que narra es un ensayo sobre la sociología como disciplina.

La verdad рагесіега no envejecer, como los hombres, mientras se la cultive y se pelee, mientras haya quienes recuerden. «¿Acumular imágenes es resistir? ¿Es posible devolverles ahora el gesto desafiante?», se pregunta Albertina, en la voz de Analía Couceyro, en el cortometraje Restos (2010). Podríamos decir que sí, siempre y cuando la historia forme parte de esa acumulación. Quizás allí esté la diferencia entre memoria y archivo, entre recuerdo y reencuentro, entre verdad y posverdad en estos tiempos.

Roa Bastos trabajó como guionista de Armando Bo, de Lautaro Murúa, de Lucas Demare; Carri padre hizo el guion de su propio libro; Carri hija recupera las lecturas de un tiempo difícil, de violencias, de compromisos, de luchas, de producción artística. La última película de la cineasta se configura como una acción cuatrerista, que usurpa la memoria, que toma la historia por asalto y que la transforma en una narrativa que intenta comprender un poco más la imagen, la historia y la política. Así, la película nos invita a ser parte, a constituirnos en cuatreros de la verdad y de la memoria. 


\section{Referencias bibliográficas}

Carri, R. [1968] (2015). Isidro Velázquez. Formas pre revolucionarias de la violencia. Obras Completas. Tomo 1. Buenos Aires, Argentina: Ediciones Biblioteca Nacional.

Roa Bastos, A. (2017). Encuentro con el Traidory otros cuentos. La Plata, Argentina: Mil Botellas.

\section{Filmografía}

Carri, A. (Directora) (2016). Cuatreros [Película documental]. Argentina.

Carri, A. (Directora) (2010). Restos [Película documental]. Argentina.

Carri, A. (Directora) (2003). Los rubios [Película documental]. Argentina

Szir, P. y Stantic, L. (Directores) (1971-1972). Los Velázquez. Argentina.

\section{Nota}

1 Pasaje extraído del off de Cuatreros (2016).

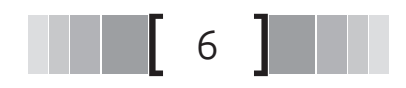

